\title{
PENDEKATAN ALTERNATIF DALAM PELAKSANAAN SUPERVISI PENGAJARAN
}

\section{Imam Gunawan*}

\begin{abstract}
Teaching supervision may aim to create a better learning atmosphere, guide teachers' teaching experience, and help the teacher assess their students. A supervisor motivation to teachers can improve their commitment. There are approaches to supervision and dimensions to classify teachers to help supervisors select the approach to adopt. Among the approaches are the clinic, directive, non-directive, collaborative, informal, collegial, and individual related to teacher dimensions such as extent of attention, responsibility, maturity, and cognitive complexity of the teachers which ease to choose recommended approaches to apply in the supervising.
\end{abstract}

Key words: Alternative Approaches, Teaching Supervision

\begin{abstract}
Abstrak
Supervisi pengajaran bertujuan mengembangkan situasi pengajaran yang lebih baik, membimbing pengalaman mengajar guru, dan membantu guru menilai kemajuan siswa. Pemberian motivasi supervisor kepada guru dapat menjadi potensi untuk peningkatan komitmen guru. Para ahli mengemukakan berbagai macam pendekatan supervisi dan dimensi dalam mengklasifikasi guru, sehingga supervisor dapat memilih pendekatan dan gaya dalam melaksanakan supervisi. Berbagai pendekatan yang dikemukakan oleh ahli mencakup supervisi klinis, pendekatan direktif, pendekatan nondirektif, pendekatan kolaboratif, pendekatan informal, kolegial, dan individual dihubungkan dengan dimensi guru mencakup tingkat perhatian guru, tingkat tanggung jawab, kematangan kepribadian, dan kompleksitas kognitif guru akan memberikan berbagai bentuk rekomendasi pendekatan alternatif dalam pelaksanaan supervisi.
\end{abstract}

Kata Kunci: Pendekatan Alternatif, Supervisi Pengajaran

* Imam Gunawan adalah Dosen Prodi PGSD IKIP PGRI Madiun

\section{A. PENDAHULUAN}

Perkembangan ilmu pengetahuan dan teknologi yang semakin pesat menuntut lembaga pendidikan untuk lebih dapat menyesuaikan dengan arus perkembangan tersebut. Personil sekolah yang memadai kemampuannya menjadi 
perhatian utama bagi setiap lembaga pendidikan. Di antara personil yang ada, guru merupakan jajaran terdepan dalam menentukan kualitas pendidikan. Guru setiap hari bertatap muka dengan siswa dalam proses pengajaran. Karena itu guru yang berkualitas sangat diperlukan oleh setiap sekolah.

Fungsi utama supervisi pengajaran adalah perbaikan dan peningkatan kualitas pengajaran serta pembinaan pengajaran sehingga terus dilakukan perbaikan pengajaran (Sahertian, 2000:131). Supervisi pengajaran bertujuan mengembangkan situasi kegiatan pengajaran yang lebih baik ditujukan pada pencapaian tujuan pendidikan sekolah, membimbing pengalaman mengajar guru, menggunakan alat pengajaran yang modern, dan membantu guru dalam menilai kemajuan siswa.

Pandangan kontingensi supervisi pengajaran didasarkan pada pemikiran bahwa setiap guru berbeda. Para ahli mengemukakan berbagai macam pendekatan supervisi dan dimensi dalam mengklasifikasi guru, sehingga supervisor dapat memilih pendekatan dan gaya dalam melaksanakan supervisi. Glickman (1981) menekankan pada dua aspek yaitu derajat komitmen dan derajat abstraksi guru. Kolb, dkk. mengemukakan beberapa hal yang perlu diperhatikan supervisor adalah konsep bagaimana dan gaya pengajaran guru, variasi strategi mengajarnya, gaya dalam pemecahan masalah, dan variasi perkembangan diri guru (Sergiovanni, 1991). Supervisor juga perlu memberikan motivasi kepada guru. Veniard mengemukakan motivation is the art of helping people to focus their minds and energies on doing their work as effectively as possible (Williams, 2006:109). Motivasi adalah seni membantu orang supaya fokus kepada pikiran mereka dan energi yang mendorong mereka bekerja secara efektif.

Model supervisi alternatif memadukan berbagai pendekatan supervisi, mencakup supervisi klinis, pendekatan direktif, pendekatan nondirektif, pendekatan kolaboratif, pendekatan informal, kolegial, dan individual; dengan dimensi guru, mencakup tingkat perhatian guru, tingkat tanggung jawab, kematangan kepribadian, dan kompleksitas kognitif. Perpaduan dari berbagai pendekatan supervisi oleh supervisor dapat meningkatkan nilai lebih dan bermakna dari pelaksanaan supervisi dan membantu guru dalam meningkatkan kualitas pengajaran.

Supervisor memperhatikan teori motivasi dalam pelaksanaan supervisi, seperti teori motivasi yang dikemukakan McClellend. Teori kebutuhan McClellend terfokus pada tiga kebutuhan yaitu prestasi, kekuasaan, dan kelompok pertemanan (Robbins, 2003:222-223). Kebutuhan berprestasi memandang guru memiliki dorongan untuk unggul, berprestasi berdasarkan standar, dan berupaya keras supaya sukses mencapainya. Kebutuhan kekuasaan memandang guru memiliki dorongan untuk membuat orang lain berperilaku dalam suatu cara yang sedemikian rupa (tanpa paksaan) sehingga mereka tidak akan berperilaku sebaliknya. Kebutuhan akan kelompok pertemanan memandang guru memiliki hasrat untuk menjalin hubungan antarpribadi yang ramah dan akrab (kolegial).

Pemberian motivasi supervisor kepada guru dapat menjadi potensi besar untuk peningkatan komitmen guru dalam bekerja. Pemberian motivasi dan pembinaan guru dilakukan sesuai dengan kondisi dan perkembangan dimensi guru yang disupervisi. Pemahaman dimensi/karakteristik guru oleh supervisor 
dijadikan dasar dalam pelaksanaan supervisi, sehingga hasil dari supervisi sesuai dengan tujuan yaitu peningkatan kualitas pengajaran yang dilaksanakan oleh guru dalam kelas.

\section{B. PEMBAHASAN}

\section{Supervisi Pengajaran}

Supervisi berasal dari kata supervision yang terdiri dari dua kata yaitu super yang berarti lebih; dan vision yang berarti melihat atau meninjau. Secara terminologi supervisi diartikan sebagai serangkaian usaha bantuan pada guru. Sehingga supervisi secara etimologis mempunyai konsekuensi disamakannya pengertian supervisi dengan pengawasan dalam pengertian lama, berupa inspeksi sebagai kegiatan kontrol yang otoriter. Supervisi diartikan sebagai pelayanan yang disediakan oleh pemimpin untuk membawa guru (orang yang dipimpin) agar menjadi guru atau personil yang semakin cakap sesuai dengan perkembangan ilmu pengetahuan pada umumnya dan ilmu pendidikan khususnya agar dapat meningkatkan keefektifan proses pembelajaran di sekolah.

Supervisi terutama sebagai bantuan yang berwujud layanan profesional yang dilakukan oleh kepala sekolah, penilik sekolah, dan pengawas serta supervisor lainnya untuk meningkatkan proses dan hasil belajar. Jika yang dimaksudkan supervisi adalah layanan profesional untuk meningkatkan proses dan hasil belajar, maka banyak pakar yang memberikan batasan supervisi sebagai bantuan kepada staf untuk mengembangkan situasi pengajaran yang lebih baik. Adams dan Dickey (1999) memberikan batasan sebagai perencanaan program perbaikan pembelajaran. Sementara itu Wiles (1997) memberikan batasan supervisi yaitu supervision is service activity that exits to help teacher do their job better. Berdasarkan pengertian tersebut disimpulkan supervisi adalah:

a. Serangkaian bantuan yang berwujud layanan profesional,

b. Layanan profesional tersebut diberikan oleh orang yang lebih ahli (kepala sekolah, penilik sekolah, pengawas, dan ahli lainnya) kepada guru,

c. Maksud layanan profesional tersebut adalah agar dapat meningkatkan kualitas proses dan hasil belajar sehingga tujuan pendidikan yang di rencanakan dapat dicapai.

Batasan supervisi yang demikian ini sekaligus mereduksikan supervisi model lama. Supervisi model lama lebih mencerminkan pengertian supervisi dari segi etimologis. Dimana super diartikan sebagai atas, sedangkan visi diartikan melihat. Dengan demikian supervisi berarti melihat dari atas. Oleh karena itu secara etimologis supervisi diartikan melihat dari atas. Maka praktik-praktik supervisi lebih banyak mengarah ke inspeksi, kepenilikan, dan kepengawasan. Apa yang disebut sebagai supervisi, pada kenyataannya adalah inspeksi (Nawawi, 1983). Gwynn (1991:8) mengemukakan supervision oroginated inspection of school and continued with that its major emphasis to about 1920. Supervisi dengan model lama (inspeksi) dapat menyebabkan guru merasa takut, tidak bebas dalam melaksanakan tugas, dan merasa terancam keamanannya bila bertemu dengan supervisor, tidak memberikan dorongan bagi kemajuan guru. Oleh karena itu, semua kegiatan pembaharuan pendidikan, termasuk pembaharuan 
kurikulumnya, yang dilakukan dengan pengerahan waktu, biaya, dan tenaga bisa menjadi sia-sia.

Carter mengemukakan bahwa supervisi adalah segala usaha dari petugas sekolah dalam memimpin guru dan petugas lainnya dalam memperbaiki pembelajaran yang mencakup menstimulir, menyeleksi pertumbuhan jabatan dan perkembangan guru, merevisi tujuan pendidikan lembaga pendidikan, bahan, metode, dan evaluasi pembelajaran (Soetopo dan Soemanto, 1984:39). Program supervisi bertumpu pada satu prinsip yang mengakui bahwa setiap manusia mempunyai potensi untuk berkembang. Supervisi merupakan suatu teknik pelayanan yang tujuan utamanya mempelajari dan memperbaiki secara bersama faktor yang mempengaruhi pertumbuhan dan perkembangan peserta didik.

Kepala sekolah sebagai pimpinan sekolah memiliki kewajiban membina kemampuan para guru. Dengan kata lain kepala sekolah hendaknya dapat melaksanakan supervisi secara efektif. Sementara ini pelaksanaan supervisi di sekolah seringkali masih bersifat umum. Aspek-aspek yang menjadi perhatian kurang jelas, sehingga pemberian umpan balik terlalu umum dan kurang mengarah ke aspek yang dibutuhkan guru. Sementara guru sendiri pun kadang kurang memahami manfaat supervisi. Hal ini disebabkan tidak dilibatkannya guru dalam perencanaan pelaksanaan supervisi. Padahal proses pelaksanaan supervisi yang melibatkan guru sejak tahap perencanaan memungkinkan guru mengetahui manfaat supervisi bagi dirinya. Supervisi merupakan pendekatan yang melibatkan guru sejak tahap perencanaan. Supervisi merupakan jawaban yang tepat untuk mengatasi kekurangtepatan permasalahan yang berhubungan dengan guru pada umumnya.

Kepala sekolah diharapkan memahami dan mampu melaksanakan supervisi karena keterlibatan guru sangat besar mulai dari tahap perencanaan sampai dengan analisis keberhasilannya. Salah satu usaha untuk meningkatkan kualitas guru ialah melalui proses pembelajaran dan guru merupakan komponen sumber daya manusia yang harus dibina dan dikembangkan secara terus menerus agar dapat melaksanakan fungsinya secara profesional (Sahertian, 2000:1). Pelaksanaan supervisi yang diasumsikan merupakan pelayanan pembinaan guru diharapkan dapat memajukan dan mengembangkan pengajaran agar guru dapat mengajar dengan baik dan berdampak pada belajar siswa. Supervisi berfungsi membantu guru dalam mempersiapkan pelajaran dengan mengkoordinasi teori dengan praktik.

Pandangan guru terhadap supervisi cenderung negatif yang mengasumsikan bahwa supervisi merupakan model pengawasan terhadap guru dengan menekan kebebasan guru untuk menyampaikan pendapat. Hal ini dapat dipengaruhi sikap supervisor seperti bersikap otoriter, hanya mencari kesalahan guru, dan menganggap lebih dari guru karena jabatannya. Guru pada dasarnya tidak membenci supervisi, tetapi tidak suka terhadap gaya supervisor. Kasus guru senior cenderung menganggap supervisi merupakan kegiatan yang tidak perlu karena menganggap bahwa telah memiliki kemampuan dan pengalaman yang lebih. Self evaluation merupakan salah satu kunci pelayanan supervisi karena dengan self evaluation supervisor dan guru dapat mengetahui kelebihan dan 
kelemahan masing-masing sehingga dimungkinkan akan memperbaiki kekurangan dan meningkatkan kelebihan tersebut secara terus menerus.

Fungsi utama supervisi adalah perbaikan dan peningkatan kualitas pembelajaran serta pembinaan pembelajaran sehingga terus dilakukan perbaikan pembelajaran (Sahertian, 2000:131). Supervisi bertujuan mengembangkan situasi kegiatan pembelajaran yang lebih baik ditujukan pada pencapaian tujuan pendidikan sekolah, membimbing pengalaman mengajar guru, menggunakan alat pembelajaran yang modern, dan membantu guru dalam menilai kemajuan peserta didik. Purwanto (2003:86-87) mengemukakan fungsi supervisi menyangkut dalam bidang kepemimpinan, hubungan kemanusiaan, pembinaan proses kelompok, administrasi personil, dan bidang evaluasi.

Pelaksanaannya supervisi pengajaran berkembang melalui pendekatanpendekatan yang memiliki pijakan ilmu tertentu. Pendekatan yang dimaksud yaitu ilmiah, artistik, dan klinis (Sergiovanni, 1991). Disamping itu ada juga pendekatan yang bertitik tolak pada psikologi belajar, yaitu psikologi humanistik, kognitif, dan behavioral. Pendekatan yang muncul yaitu nondirektif, kolaboratif, dan direktif (Glickman, 1981).

Supervisi dengan pendekatan ilmiah, indikator keberhasilan mengajar dilihat dari komponen-komponen pembelajaran, variabel-variabel proses belajar mengajar. Sehingga pusat perhatian pendekatan ilmiah lebih ditekankan pada pengembangan komponen pembelajaran secara keseluruhan. Supervisi dengan pendekatan artistik menurut Eisner, dalam melihat berhasil tidaknya pengajaran, usaha meningkatkan mutu guru banyak menekankan pada kepekaan, persepsi, dan pengetahuan supervisor (Sergiovanni, 1991). Supervisor diharapkan dapat mengapresiasi kejadian pengajaran yang bersifat "subtleties" (lembut). Pendekatan ini menempatkan supervisor sebagai instrumen observasi dalam mencari data untuk keperluan supervisi.

Supervisi klinis merupakan suatu bentuk bimbingan profesional yang diberikan kepada guru berdasarkan kebutuhannya melalui siklus yang sistematik dalam perencanaannya, observasi yang cermat atas pelaksanaan, dan pengkajian balikan dengan segera dan obyektif tentang penampilan mengajarnya yang nyata, untuk meningkatkan keterampilan mengajar dan sikap profesional guru itu. Pemberian bimbingan berbentuk bantuan sesuai kebutuhan guru yang bersangkutan, dan dilakukan dengan berbagai upaya (observasi secara sistematis, analisis data balikan) sehingga guru menemukan sendiri cara-cara meningkatkan dirinya melalui analisis bersama. Di dalam kata "klinis" tersirat cara kerja di bidang medis, dimana pihak yang memerlukan pertolongan itu datang atas prakarsa sendiri karena menyadari akan sesuatu kekurangan (gangguan kesehatan), dianalisis berdasarkan keluhan-keluhan pasien, dan pada akhirnya diberikan terapi.

Sergiovanni (1991) mengemukakan kegiatan supervisi klinis dilakukan dalam lima tahap, seperti pada Gambar 1. 


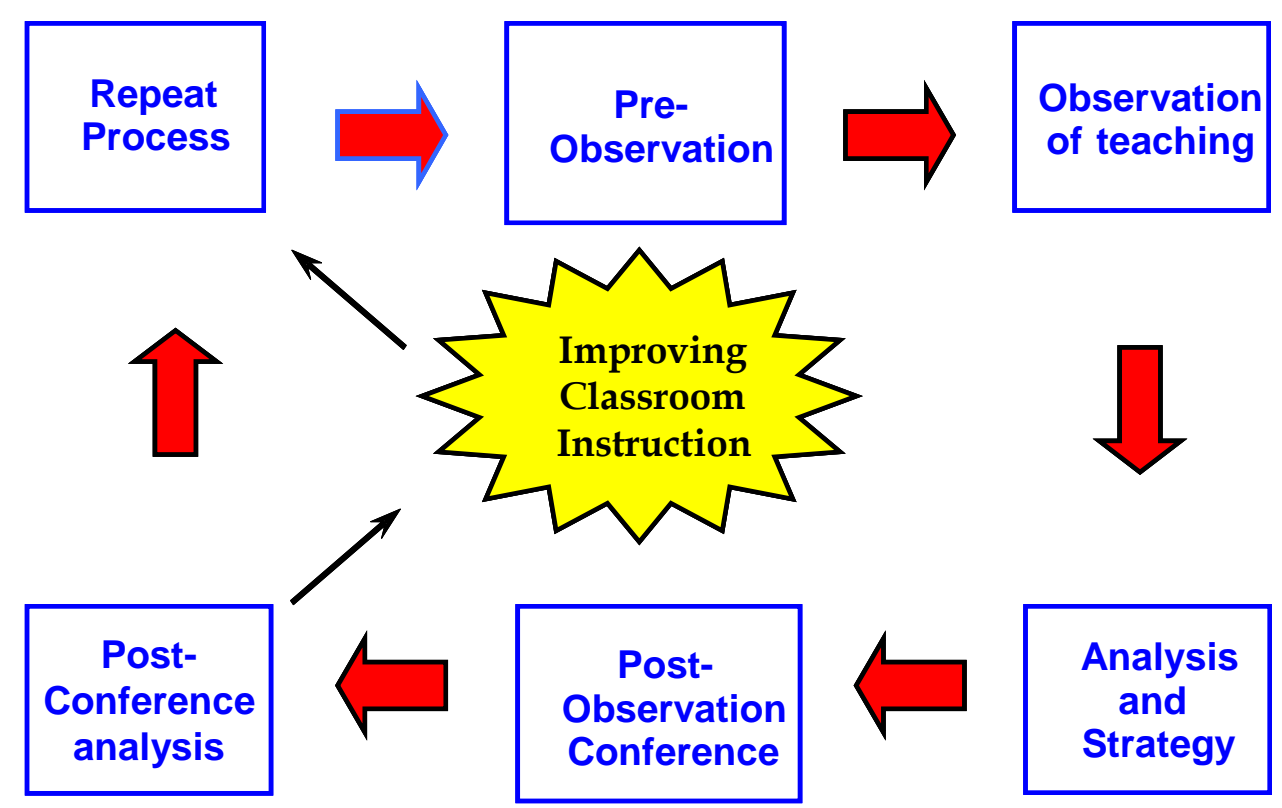

Gambar 1 Tahapan Supervisi Klinis (Adaptasi Sergiovanni, 1991)

Tahap preobservation conference (pertemuan sebelum observasi) dilakukan pembicaraan antara supervisor dan guru yang akan melatihkan kemampuannya, kemudian dilanjutkan kegiatan supervisor mengobservasi guru yang sedang mengajar (observation of teaching). Pada langkah ini supervisor mengumpulkan sejumlah data perilaku guru yang sedang mengajar. Selanjutnya supervisor menganalisis awal data yang ada dan menentukan strategi untuk membantu guru (analysis and strategy). Supervisor mempertimbangkan kontrak yang telah disepakati dengan guru, evaluasi selama guru mengajar, kualitas hubungan interpersonal antara guru dan supervisor, kompetensi, dan pengetahuan guru.

Langkah selanjutnya postobservation conference (pertemuan setelah observasi). Pada langkah ini dibicarakan hasil observasi supervisor terhadap guru yang sedang mengajar. Guru memecahkan masalahnya dengan bantuan supervisor. Langkah yang terakhir pelaksanaan supervisi klinis yaitu analisis kegiatan setelah pertemuan guru dan supervisor (postconference analysis). Akhir dari langkah ini disepakatinya tindakan lanjutan yang perlu dilaksanakan pada waktu yang berikutnya. Dengan demikian maka hasil dari supervisi klinis yang telah dilakukan dapat digunakan sebagai bahan pelaksanaan supervisi klinis pada tahap berikutnya.

Pendekatan nondirektif, kolaboratif, direktif dilaksanakan berdasar kondisi dan perkembangan kemampuan guru yang disupervisi. Glickman (1981) menekankan pada dua aspek yaitu derajat komitmen dan derajat abstraksi guru. Dari dua aspek ini ia membagi guru dalam empat kelompok (kuadran). Lebih jelasnya dapat dilihat pada Gambar 2.

Guru yang memiliki derajat abstraksi rendah dan derajat komitmen rendah (Kuadran I guru yang drop out) pendekatan supervisi yang tepat adalah direktif. 
Supervisor banyak mengarahkan guru. Kegiatannya menginformasikan, mengarahkan, menjadi model, menetapkan patokan tingkah laku, dan menilai serta menggunakan insentif sosial dan material. Guru yang memiliki derajat abstraksi rendah dan derajat komitmen tinggi (Kuadran II guru kerjanya tak berfokus) atau guru yang memiliki derajat abstraksi yang tinggi namun komitmennya rendah (Kuadran III guru yang pengamat analitik) pendekatan supervisi yang cocok adalah kolaboratif. Supervisor berkolaborasi dengan guru. Kegiatan supervisor adalah mempresentasikan persepsinya mengenai sesuatu yang menjadi sasaran supervisi, menanyakan guru mengenai persepsinya terhadap sasaran supervisi, mendengarkan guru, mengajukan alternatif pemecahan masalah, bernegosiasi dengan guru.

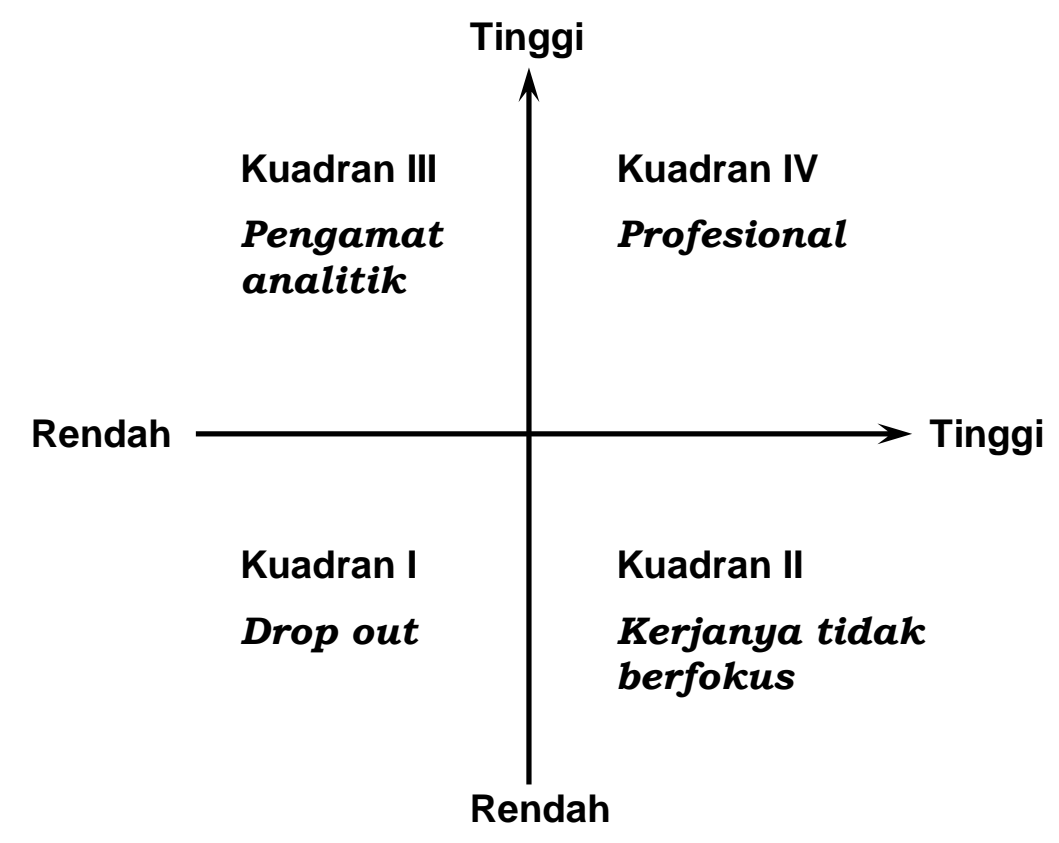

\section{Keterangan:}

- Garis horizontal $=$ Derajat komitmen,

- Garis vertikal = Derajat abstraksi.

\section{Gambar 2 Kuadran Guru}

Guru yang memiliki derajat abstraksi tinggi dan juga derajat komitmen tinggi (Kuadran IV guru profesional) pendekatan supervisi yang tepat adalah nondirektif. Yang dilakukan supervisor adalah mendengarkan, memperhatikan dan mendiskusikan dengan guru, membangkitkan kesadaran sendiri, bertanya dan mengklarifikasi pengalaman guru. Implementasi kemampuan profesional guru mutlak diperlukan sejalan diberlakukannya otonomi daerah, khususnya bidang pendidikan. Kemampuan profesional guru akan terwujud apabila guru memiliki kesadaran dan komitmen yang tinggi dalam mengelola interaksi belajar-mengajar pada tataran mikro, dan memiliki kontribusi terhadap upaya peningkatan mutu pendidikan pada tataran makro. 


\section{Tingkat Kompleksitas Kognitif Guru}

Klasifikasi kompleksitas guru berdasarkan pada tingkatan pertumbuhan kognitif guru yang ditunjukkan dalam kegiatan pengajaran. Berdasarkan kompleksitas kognitif, Harvey mengklasifikasikan guru menjadi dua kategori yaitu tingkat kompleksitas kognitif rendah dan kompleksitas kognitif tinggi (Sergiovanni, 1991). Guru yang termasuk dalam kompleksitas kognitif rendah memiliki ciri-ciri yaitu pola pikir guru bersifat konkret, praktis, dan sederhana. Guru yang termasuk dalam kompleksitas kognitif tinggi memiliki ciri-ciri yaitu berpikir kompleks, cenderung dapat menerapkan variasi strategi mengajar, memahami keterkaitan, perbedaan, dan persoalan suatu konsep, dan dapat merefleksikan konsep tersebut dalam pengajaran.

Supervisor dituntut memiliki strategi untuk meningkatkan kompleksitas kognitif guru dengan tujuan guru dapat menstimulasi lingkungan pengajaran. Upaya ini dilakukan dengan memberikan kesempatan kepada guru untuk mengemukakan tentang pengajarannya, mengevaluasi pengajaran, merefleksikan pengajaran, dan melakukan eksperimen dalam lingkungan pengajaran. Sehingga guru dalam hal ini lebih banyak bicara, supervisor lebih banyak mendengar, memberi pengarahan, dan saran.

Guru diharapkan memiliki tanggung jawab dari hasil pengajarannya. Supervisor yang memperhatikan berbagai pendekatan supervisi dengan mengombinasikan berbagai pendekatan tersebut dapat memberikan nilai lebih dan bermakna pada pelaksanaan supervisi. Harvey mengemukakan dengan memberikan stimulus kepada guru dalam hal intelektual, tantangan, dan dukungan dapat meningkatkan kompleksitas kognitif guru, sehingga kualitas pengajaran juga meningkat (Sergiovanni, 1991).

\section{Gaya Pengajaran Guru}

Karakteristik situasional yang dipertimbangkan dalam pandangan kontingensi adalah gaya pengajaran dan motivasi guru dalam bekerja. Guru memiliki ciri khas tersendiri dalam mengajar dan menyelesaikan masalah pengajaran. Supervisor dituntut memiliki catatan tentang guru sebagai bahan refleksi dan mengakomodasi peran dan tugas guru. Kolb, dkk. mengemukakan model, konsep pengajaran, dan pemecahan masalah merupakan sebagai suatu proses (Sergiovanni, 1991). Model pengajaran cenderung meningkatkan pengertian cara siswa membangkitkan pengetahuan dari konsep pengalaman, aturan, dan prinsip yang menuntun tindakan mereka dalam situasi dan cara siswa memodifikasi konsep tersebut untuk meningkatkan efektivitas dalam pengajaran.

Lebih lanjut Kolb, dkk. mengemukakan empat tahap yang ditampilkan dalam pengajaran yaitu: (1) pengalaman konkret; (2) kemampuan dalam mengolah pengalaman dalam bentuk mengobservasi dan refleksi; (3) perumusan konsep dan generalisasi; dan (4) bereksperimen dengan apa yang dipelajari dalam latar yang baru (Sergiovanni, 1991). Keempat tahapan tersebut merupakan siklus yang prosesnya terus berputar dan berkelanjutan. Tahap yang ditampilkan guru dalam pengajaran seperti pada Gambar 3. 


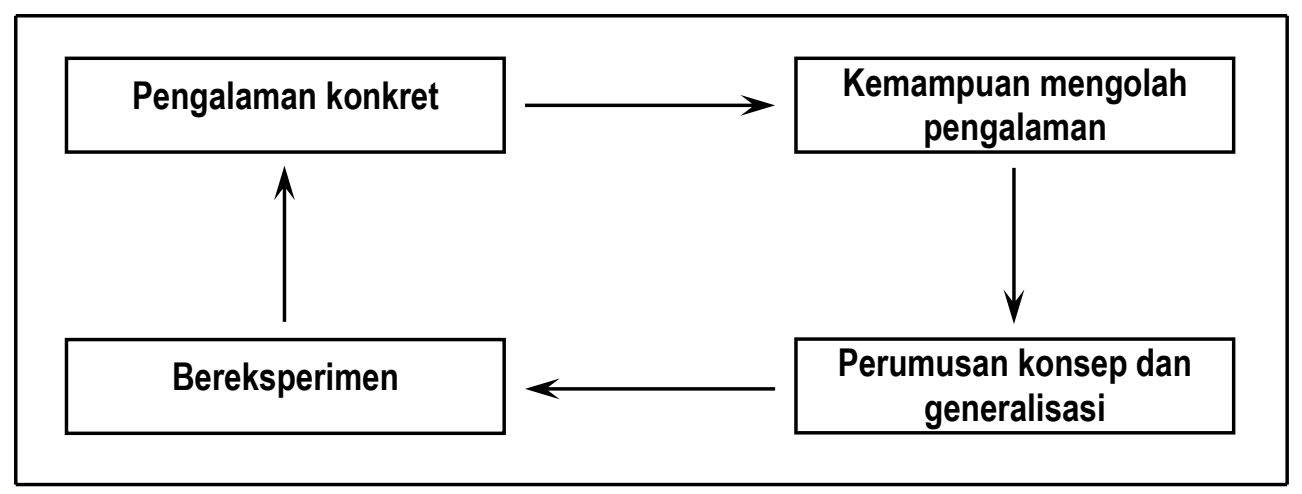

Gambar 3 Tahap yang Ditampilkan Guru dalam Pengajaran

Guru mendapatkan pengalaman konkret dari lingkungannya tentang sesuatu hal khususnya dalam pengajaran. Pengalaman tersebut diolah oleh guru, guru menganalisis pengalaman tersebut sehingga menjadi suatu pemahaman konsep baru. Pada tahap ini guru melakukan generalisasi dari hasil analisisnya. Hasil dari proses tersebut akan diuji kebenarannya dengan bereksperimen. Dari kegiatan eksperimen tersebut guru akan mengetahui kebenaran suatu konsep dan berinteraksi dengan orang lain sehingga akan mendapatkan pengalaman konkret baru lagi. Tahap ini akan terus berulang-ulang dan semakin kompleks aspeknya.

Lebih lanjut Kolb, dkk. mengidentifikasi empat perbedaan gaya pengajaran guru yaitu: (1) concrete experience (pengalaman konkret); (2) reflective-observation (refleksi-observasi); (3) abstract conceptualization (pemahaman abstrak); dan (4) active experimentation (percobaan aktif) (Sergiovanni, 1991). Pengajaran tahap concrete experience (CE) siswa dilibatkan secara penuh, terbuka, dan tanpa bias dari pengalaman baru. Tahap reflective observation (RO) siswa mampu merefleksikan dan mengobservasi pengalaman dari banyak perspektif. Tahap abstract conceptualization (AC) siswa mampu mendeskripsikan konsep secara integratif (teoritik dan empirik). Tahap active experimentation (AE) siswa mampu menggunakan teori untuk membuat keputusan dan menyelesaikan masalah.

Guru melaksanakan pengajaran cenderung menerapkan keempat tahap tersebut, yang membedakan adalah tingkat pemahaman dalam tiap tahap. Secara praktis tujuannya adalah lebih menggunakan pemikiran guru sebagai orientasi melaksanakan pengajaran yang terencana secara tertulis. Pengajaran merupakan suatu perbuatan yang kompleks (a highly complexion process) karena dituntut adanya kemampuan personal, profesional, dan sosial kultural secara terpadu dalam proses pengajaran harus tercipta.

\section{Gaya Pengajaran Guru dan Pilihan Pendekatan Supervisor}

Gaya pengajaran guru digunakan pertimbangan dalam menentukan pendekatan sehingga pemberian supervisi sesuai dengan kebutuhan guru. Pemilihan pendekatan dipengaruhi oleh pemahaman supervisor tentang pemahaman teori, interpretasi, dan pengalaman yang dimiliki supervisor. Supervisor perlu melakukan kajian tentang segala hal yang dialami guru atau 
karakteristik guru itu sendiri. Acheson dan Meredith (1987) mengemukakan bahwa kegiatan supervisi terpusat pada guru, supervisor bersifat sebagai fasilitator guru dalam menyelesaikan permasalahan pengajaran.

Supervisi kolegial cocok digunakan pada guru yang memiliki gaya pengajaran concrete experience (pengalaman konkret). Supervisi kolegial digunakan pada guru yang telah bersedia bekerja sama dengan guru lain dan berorientasi pada pencapaian pengalaman konkret. Guru diberi kesempatan untuk berinteraksi dan berdiskusi dengan guru lain membahas tentang tugasnya. Berbagai pengalaman konkret yang dialami guru dicatat, dilakukan interpretasi, dan pengalaman yang menarik dan unik dapat dipraktikkan oleh guru lain di kelasnya. Tipe guru seperti ini tidak suka dengan pengembangan profesional secara individual. Pendekatan kolegial memungkinkan guru mendapatkan pengalaman konkret, memiliki pengalaman abstrak, dan observasi refleksi.

Guru pada saat berdiskusi dengan guru lainnya diharapkan dapat menemukan ide baru yang akan diterapkan dalam pengajaran. Guru dapat mengadopsi metode mengajar guru lain untuk diterapkan di kelasnya. Kemungkinan pada awal menerapkan metode baru guru mengalami kesulitan. Dengan demikian guru memiliki tantangan untuk melakukan perubahan dan berinovasi dalam pengajarannya untuk menciptakan situasi belajar yang lebih baik, terus melakukan modifikasi sesuai dengan materi dan media yang digunakan dalam pengajaran. Guru akan terlatih dalam melaksanakan inovasi secara berkelanjutan dan diharapkan akan meningkatkan kualitas pengajaran.

Guru yang memiliki gaya pengajaran reflective-observation (refleksiobservasi) cocok dengan pendekatan kolegial, karena memiliki tingkat refleksiobservasi tinggi, suka merespons, dan senang bekerja dengan guru lain. Namun dalam kasus tertentu guru akan bertindak pasif, lebih suka sebagai observer, dan aktif mengambil sesuatu dari pengamatan yang dilakukan. Maka pendekatan yang dilakukan adalah secara individual. Guru yang berkarakter refleksi cenderung tidak banyak mengalami kemajuan. Sehingga supervisor memberikan bantuan dalam pengembangan dengan membuat kontrak yang terencana agar guru fokus dalam pengajaran. Target dan tujuan dirumuskan secara spesifik agar dapat mengatasi permasalahan guru dalam kelas. Guru dituntut berorientasi pada aksi (pelaksanaan) pengajaran dan kegiatan supervisor mendorong agar target dan tujuan yang telah dirumuskan dapat tercapai.

Guru yang berorientasi konseptual-abstrak lebih terfokus dalam pengajaran dan gagasan teori dalam mengatasi permasalahan. Mereka mengkaji ide secara teori, melakukan penelitian mengenai pengajaran, dan berdiskusi dalam permasalahan pengajaran. Guru yang berorientasi konseptual-abstrak dalam membuat keputusan berdasarkan pada data. Guru merencanakan dan menyiapkan instrumen secara sistematis dalam pengajaran. Kegiatan supervisor adalah memberikan motivasi agar guru perencanaan yang telah dirumuskan dapat dilaksanakan dengan baik dan hasilnya (fakta) dijadikan pedoman dalam menyusun perencanaan pengajaran selanjutnya.

Guru yang berkarakter abstract conceptualization (pemahaman abstrak) cenderung memudahkan supervisor karena dalam menyelesaikan masalah berdiskusi dengan guru lain. Namun terkadang mereka mempengaruhi kelompok 
lain dengan mengemukakan teori/konsep dalam menyelesaikan masalah. Guru yang berkarakter abstract conceptualization (pemahaman abstrak) lebih suka menggunakan teori dalam mengimplementasikan proses pengajaran. Walaupun demikian guru perlu juga memperhatikan fakta (nyata) dalam pengajaran. Sehingga supervisor dituntut dapat menyeimbangkan perbedaan guru yang berorientasi abstract conceptualization (pemahaman abstrak) dengan active experimentation (percobaan aktif).

Guru yang termasuk dalam karakter active experimentation (percobaan aktif) cenderung mengkaji kegiatan pengajaran sebagai suatu yang bersifat fakta (nyata), kegiatan pengajaran tidak berpijak pada teori. Mereka terfokus pada fakta pada proses pengajaran. Sehingga supervisor kegiatannya membantu guru secara praktis dalam memandang kegiatan pengajaran, kebermaknaan pengajaran, dan meningkatkan kinerja guru.

Pendekatan kolegial kurang sesuai jika digunakan pada guru yang tidak suka berinteraksi dengan guru lain dan lebih suka bekerja sendiri. Pilihan pendekatan pada tipe guru seperti ini yang sesuai adalah pendekatan direktif. Supervisor mendorong guru melakukan eksperimen secara aktif. Guru yang termasuk dalam tipe ini suka bertindak sendiri dalam bekerja. Mereka berani mengambil risiko dalam melaksanakan hal baru (inovasi) dalam pengajaran. Pendekatan individual memberi kesempatan kepada guru untuk tumbuh dan berkembang sesuai dengan kemampuan guru. Mereka hanya memerlukan bantuan dalam hal bereksperimen dan merefleksikan proses pengajaran.

Pendekatan kolegial bagi guru yang individual dipersepsikan sebagai penghalang dalam pengembangan profesionalnya. Mereka berpandangan dengan berdiskusi dapat membuat proses pengembangan profesionalnya terhambat karena harus menunggu guru lain jika ada guru yang belum atau tidak dapat mengimbangi tingkat pemahamannya terhadap sesuatu hal.

\section{Pendekatan Supervisor dan Kompleksitas Kognitif}

Supervisor dapat memilih alternatif dalam memberikan bantuan dan pembinaan kepada guru. Supervisor dapat memilih berdasarkan teori yang dikemukakan oleh Glickman (1981) yang membagi menjadi tiga pendekatan yaitu direktif, kolaboratif, dan nondirektif. Pendekatan direktif, kolaboratif, dan nondirektif dilaksanakan berdasar kondisi dan perkembangan kemampuan guru yang di supervisi, dengan menekankan pada dua aspek yaitu derajat komitmen dan derajat abstraksi guru. Pendekatan direktif dilaksanakan pada guru yang memiliki derajat abstraksi dan komitmen yang rendah (guru drop out). Supervisor banyak mengarahkan guru. Kegiatannya menginformasikan, mengarahkan, menjadi model, menetapkan patokan tingkah laku, dan menilai serta menggunakan insentif sosial dan material.

Pendekatan kolaboratif dilaksanakan pada guru yang memiliki derajat abstraksi rendah dan derajat komitmen tinggi (guru kerjanya tak berfokus) atau guru yang memiliki derajat abstraksi yang tinggi namun komitmennya rendah (guru yang pengamat analitik). Supervisor berkolaborasi dengan guru. Kegiatan supervisor adalah mempresentasikan persepsinya mengenai sesuatu yang menjadi sasaran supervisi, menanyakan guru mengenai persepsinya terhadap sasaran 
supervisi, mendengarkan guru, mengajukan alternatif pemecahan masalah, bernegosiasi dengan guru.

Pendekatan nondirektif dilaksanakan pada guru yang memiliki derajat abstraksi tinggi dan juga derajat komitmen tinggi (guru profesional). Kegiatan supervisor adalah mendengarkan, memperhatikan dan mendiskusikan dengan guru, membangkitkan kesadaran sendiri, bertanya, dan mengklarifikasi pengalaman guru.

Berbagai pendekatan yang dikemukakan oleh ahli yang mencakup supervisi klinis, pendekatan direktif, pendekatan nondirektif, pendekatan kolaboratif, pendekatan informal, kolegial, dan individual dihubungkan dengan dimensi guru yang mencakup tingkat perhatian guru, tingkat tanggung jawab, kematangan kepribadian, dan kompleksitas kognitif guru sehingga akan memberikan berbagai pendekatan alternatif dalam pelaksanaan supervisi. Sergiovanni (1991) mengemukakan hubungan tingkat perhatian guru, tingkat tanggung jawab, kematangan kepribadian, kompleksitas kognitif, dan pilihan pendekatan alternatif supervisor seperti pada Gambar 4.

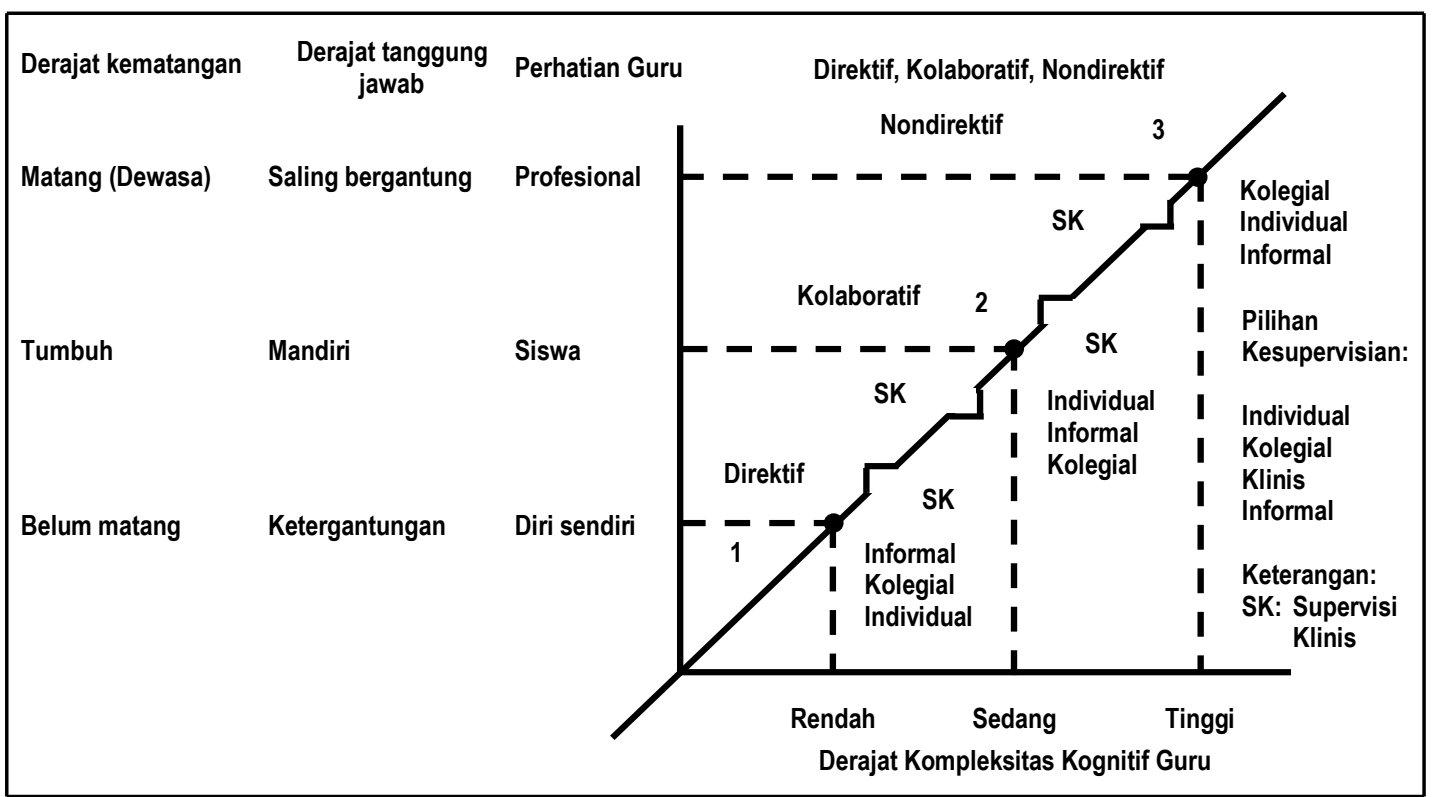

Gambar 4 Pertemuan Variabel Guru dan Gaya Supervisor

Berdasarkan Gambar 4 tentang pertemuan variabel guru dan gaya supervisor disimpulkan bahwa perhatian guru, tingkat tanggung jawab, kematangan, dan kompleksitas kognitif guru memiliki kedudukan yang sejajar dan linier. Perhatian utama guru pada masalah, kebutuhan, dan karakteristik siswa, maka guru berupaya meningkatkan kematangan dan kompleksitas kognitif. Pertemuan garis tersebut menggambarkan dimensi pengembangan guru dan rekomendasi pendekatan alternatif yang dilaksanakan supervisor.

Guru yang masuk dalam bagian titik pertemuan 1 memiliki tingkat perhatian guru, tingkat tanggung jawab, kematangan kepribadian, dan kompleksitas kognitif rendah, maka pendekatan yang sesuai adalah direktif dan karakter supervisi bersifat informal dengan menekankan pada pertemuan/interaksi 
langsung yang intensif supervisor dengan guru. Pendekatan kolegial atau individual disesuaikan dengan perkembangan dan kondisi guru. Pendekatan kolegial digunakan saat guru mampu bekerja sama dengan guru lain. Keterlibatan supervisor hanya memastikan bahwa guru mendapat petunjuk dan pembinaan yang dibutuhkan. Pendekatan individual digunakan pada saat guru memiliki permasalahan rumit dalam pengajaran.

Guru yang masuk dalam bagian titik pertemuan 2 memiliki tingkat perhatian guru, tingkat tanggung jawab, kematangan kepribadian, dan kompleksitas kognitif sedang, maka pendekatan yang sesuai adalah kolaboratif. Guru dan supervisor menyelesaikan masalah secara bersama, merencanakan supervisi, dan membuat keputusan secara kooperatif. Sehingga dalam pengembangan profesional guru lebih bersifat individual. Pendekatan informal dan kolegial digunakan jika guru memerlukan bantuan yang sekiranya guru sudah tidak dapat menyelesaikan sendiri.

Guru yang profesional merupakan bagian dalam titik pertemuan 3 memiliki tingkat perhatian guru, tingkat tanggung jawab, kematangan kepribadian, dan kompleksitas kognitif tinggi, sehingga pendekatan yang sesuai adalah nondirektif. Guru profesional lebih dapat memperhatikan persoalan siswa lebih komprehensif. Hal tersebut dapat mempengaruhi kualitas sekolah dan mencerminkan bahwa guru memiliki tingkat kompleksitas kognitif yang tinggi. Pendekatan yang cocok adalah kolegial. Pendekatan individual dan informal digunakan sesekali jika guru menghadapi permasalahan yang bersifat khusus.

Cekungan secara periodik dalam Gambar 4 menunjukkan bahwa guru memerlukan pertolongan dan pembinaan lebih intensif karena menghadapi masalah dan tantangan khusus. Permasalahan tersebut diidentifikasi oleh guru dan supervisor. Supervisor dituntut dapat menerapkan pendekatan yang efektif. Supervisi klinis sifatnya lebih ke arah yang khusus dan terbatas pada aspek tertentu yang dibutuhkan dalam pengajaran guru. Triyono (2009) berpendapat supervisi klinis adalah bentuk bantuan profesional yang diberikan pada guru berdasarkan kebutuhan dengan beberapa siklus tertentu. Siklus yang ada pada desain supervisi ini melibatkan guru sebagai target utama. Ada tiga siklus dalam pelaksanaan supervisi klinis, meliputi pertemuan awal, observasi, dan pertemuan balikan. Aplikasi ini dilakukan dengan beberapa langkah pendekatan oleh guru untuk pelaksanaan supervisi pengajaran di lapangan.

Permasalahan guru kelihatannya begitu kompleks dan memang demikian. Supervisor dituntut dapat mengakomodasi perbedaan individu dan lingkungan guru untuk menentukan strategi yang digunakan. Pada akhirnya proses memutuskan untuk memilih pendekatan supervisi adalah merupakan bentuk konsep trial dan error. Suatu model memerlukan perlakuan (treatment) dan percobaan (trial) untuk memutuskan secara cepat yang bertujuan mendapatkan umpan balik mana yang tepat dalam bekerja. Strategi yang telah dipilih dapat dipertahankan bila menunjukkan hasil yang baik, tetapi bila hasilnya tidak atau kurang baik maka perlu dipilihkan strategi lain secara berkelanjutan. 


\section{KESIMPULAN}

Supervisi bertujuan mengembangkan situasi kegiatan pengajaran yang lebih baik ditujukan pada pencapaian tujuan pendidikan sekolah, membimbing pengalaman mengajar guru, menggunakan alat pengajaran yang modern, dan membantu guru dalam menilai kemajuan siswa. Pandangan supervisi kontingensi didasarkan pada pemikiran bahwa setiap guru berbeda. Pemberian motivasi supervisor kepada guru dapat menjadi potensi besar untuk peningkatan komitmen guru dalam bekerja. Berdasarkan kompleksitas kognitif guru diklasifikasikan menjadi dua kategori yaitu tingkat kompleksitas kognitif rendah dan kompleksitas kognitif tinggi. Perhatian guru, tingkat tanggung jawab, kematangan, dan kompleksitas kognitif guru memiliki kedudukan yang sejajar dan linier.

Gaya pengajaran guru digunakan pertimbangan dalam menentukan pendekatan sehingga pemberian supervisi sesuai dengan kebutuhan guru. Pemilihan pendekatan juga dipengaruhi oleh pemahaman supervisor tentang pemahaman teori, interpretasi, dan pengalaman yang dimiliki. Seorang supervisor perlu melakukan kajian tentang segala hal yang dialami guru atau karakteristik guru itu sendiri. Sehingga prinsip supervisi yang interaktif, demokratis, dan terpusat pada guru dapat terwujud.

Berbagai pendekatan yang dikemukakan oleh ahli yang mencakup supervisi klinis, pendekatan direktif, pendekatan nondirektif, pendekatan kolaboratif, pendekatan informal, kolegial, dan individual dihubungkan dengan dimensi guru yang mencakup tingkat perhatian guru, tingkat tanggung jawab, kematangan kepribadian, dan kompleksitas kognitif guru sehingga akan memberikan berbagai pendekatan alternatif dalam pelaksanaan supervisi. Perpaduan dari berbagai pendekatan supervisi oleh supervisor dapat meningkatkan nilai lebih dan bermakna dari pelaksanaan supervisi dan membantu guru dalam meningkatkan kualitas pengajaran. 


\section{DAFTAR RUJUKAN}

Adams, H. P., dan Dickey, F. G. 1999. Basic Principles of Supervision. New York: American Book Company.

Acheson, K. A., dan Meredith, D. G. 1987. Techniques in the Clinical Supervision: Preservice and Inservice Application. London: Longman.

Glickman, C. D. 1981. Development Supervision: Alternative for Helping Teachers Improve Instructions. Virginia, Alexandria: ASCD.

Gwynn, J. M, 1991. Theory and Practice of Supervision. New York: Dood Mead Company.

Nawawi, H. 1988. Administrasi Pendidikan. Jakarta: CV. Haji Masagung.

Purwanto, M. N. 2003. Administrasi dan Supervisi Pendidikan. Bandung: Remaja Rosdakarya.

Robbins, S. P. 2003. Perilaku Organisasi. Terjemahan oleh Benyamin Molan. 2006. Jakarta: Indeks.

Sahertian, P. A. 2000. Konsep Dasar dan Teknik Supervisi Pendidikan dalam Rangka Pengembangan Sumber Daya Manusia. Jakarta: Rineka Cipta.

Sergiovanni, T. J. 1991. The Principalship: a Reflective Practice Perpective. Boston: Allyn and Bacon, Inc.

Soetopo, H., dan Soemanto, W. 1984. Kepemimpinan dan Supervisi Pendidikan. Malang: Bina Aksara.

Triyono, N. 2009. Menyimak Desain Supervisi Sekolah (Online). (http://www.kabarindonesia.com, diakses 17 Mei 2009).

Wiles, K. 1997. Supervision for Better School. New York: Prentice Hall, Inc.

Williams, K. 2006. Introducing Management a Development Guide. New York: Elsevier Ltd. 